\title{
PENGARUH SUHU DAN KERAPATAN INANG TERHADAP SUPERPARASISTISME OLEH ERIBORUS ARGENTEOPILOSUS: IMPLIKASI BAGI PENGENDALIAN HAYATI
}

\author{
Novri Nelly ${ }^{1} \&$ Damayanti Buchori ${ }^{2}$ \\ ${ }^{1}$ Jurusan Hama dan Penyakit Tumbuhan Fakultas Pertanian Universitas Andalas \\ Kampus Universitas Andalas Limau Manis Padang 25163 \\ ${ }^{2}$ Departemen Proteksi Tanaman, Fakultas Pertanian, Institut Pertanian Bogor \\ Jl. Kamper Kampus IPB Dramaga Bogor 16680 \\ E-mail: novrinelly@yahoo.com
}

\begin{abstract}
Effect of temperature and host density on superparasitisme by Eriborus argenteopilosus: Implication for biological control. Superparatism is a type of parasite in which the host is attacked by another parasitoid. Superparatism is influenced by several factors including temperature and host density. The aim of this research was to investigate the effect of temperature and host density on superparatism E. argenteopilosus. Different number of larva C. pavonana $(15,30,60,90$ and 120) was infested with a female parasitoidat various temperature $\left(20^{\circ}, 25^{\circ}\right.$, and $\left.30^{\circ} \mathrm{C}\right)$ for three hours. The larva host was disectionto enable us to count the number of eggs. The study result reveals that superparatism E. argenteopilosus was influenced by temperature and host density. Superparatism occured randomly at different temperature reaching the highest at $20^{\circ}$ with host density of 15 and 30 .
\end{abstract}

Key words: Eriborus argenteopilosus, host density, host-parasitoid interaction, superparasitsme, temperature

\begin{abstract}
ABSTRAK
Pengaruh suhu dan kerapatan inang terhadap superparasistisme oleh Eriborus argenteopilosus: Implikasi bagi pengendalian hayati. Superparasitisme adalah penerimaan inang yang telah terparasit oleh parasitoid dari spesies sama atau berbeda. Superparasitisme dipengaruhi oleh berapa faktor, diantaranya adalah suhu dan kerapatan inang. Penelitian bertujuan untuk mengukur pengaruh suhu dan kerapatan inang terhadap superparasitisme E. argenteopilosus. Pada suhu $20,25,30{ }^{\circ} \mathrm{C}$ dan sebanyak 15, 30, 60, 90 dan 120 larva C. pavonanadienfestasikan satu betina selama 3 jam. Pengamatan dilakukan dengan mendikseksi larva inang tersebut untuk menghitung jumlah telur yang diletakkan. Hasil penelitian menunjukkan bahwa superparasitisme oleh E. argenteopilosus dipengaruhi oleh suhu dan kerapatan inang. Superparasitisme terjadi secara acak pada suhu yang berbeda, tertinggi pada suhu $20{ }^{\circ} \mathrm{C}$ dengan kerapatan inang 15 dan 30 larva.
\end{abstract}

Kata kunci: Eriborus argenteopilosus, kerapatan inang, interaksi inang-parasitoid, suhu, superparasitisme

\section{PENDAHULUAN}

Pengendalian hayati dengan memanfaatkan potensi parasitoid untuk menekan populasi hama di lapangan saat ini mendapat perhatian yang serius terutama dalam kaitannya dengan merebaknya isu konservasi keanekaragaman hayati, kesehatan ekosistem, dan pengembangan teknologi alternatif (nonpestisida) bagi pengendalian hama. Berbagai upaya dilakukan untuk meningkatkan kinerja parasitoid di lapangan sebagai agens pengendali. Pada dasarnya parasitoid betina yang berperan dalam menyebabkan mortalitas hama, karena parasitoid betina yang meletakkan telur dan menyebabkan parasitisasi terjadi hama tersebut.
Banyak faktor yang menentukan parasitoid betina untuk meletakkan telur, antara lain kondisi inang, lingkungan dan fisiologi parasitoid itu sendiri. Juga jumlah parasitoid yang ada di lokasi yang sama (Husni et al., 2011). Kondisi lingkungan seperti suhu sangat mempengaruhi aktifitas parasitisasi, dan menentukan tanggap fungsional parasitoid tersebut. Hasil pengamatan terhadap tanggap fungsional E. argenteopilosus menunjukkan bahwa terjadi perbedaan tipe tanggap fungsional jika suhu lingkungan parasitoid tersebut berbeda. Hal ini menunjukkan bahwa suhu mempengaruhi aktifitas parasitoid untuk menemukan dan memarasit inang (Nelly et al., 2005). 
Pada kebanyakan spesies parasitoid, parasitoid betina mampu mendeteksi kondisi inang, yaitu membedakan antara inang yang telah terparasit atau belum, dan diistilahkan dengan host discrimination (Visser et al., 1992). Parasitoid betina akan meletakkan telurnya pada inang yang mempunyai kualitas dan kebugaran yang tinggi sehingga diperoleh keturunan yang bagus (Harvey et al., 2013). Kebugaran atau fitness parasitoid ditentukan oleh kualitas inang, sedangkan kualitas inang dipengaruhi oleh beberapa faktor yaitu: ukuran, umur, spesies, dan keadaan inang telah terparasit atau belum (Godfray, 1994).

Penerimaan inang yang telah terparasit untuk peletakkan telur oleh parasitoid betina disebut "superparasitisme" (Waage, 1986; Godfray, 1994). Peletakan telur pada inang yang telah terparasit oleh betina yang sama disebut self superparasitisme, dan jika oleh individu parasitoid betina berbeda dari spesies yang sama, dikenal dengan conspesific superparasitisme (Godfray, 1994).

Kejadian superparasitisme ini pertama kali diamati oleh Howard tahun 1897 (Godfray, 1994). Perilaku ini pada awalnya dianggap sebagai suatu kesalahan dari parasitoid dan akan merugikan parasitoid itu sendiri. Tetapi kemudian diketahui superparasitisme tidak selalu merugikan karena dianggap suatu strategi adaptasi dari parasitoid untuk mempertahankan keturunannya. Self superparasitsme pada parasitoid soliter dapat menguntungkan karena memberi peluang bagi keturunannya untuk bertahan hidup (survive) apabila harus berkompetisi di dalam inang dengan telur yang diletakan oleh individu lain. Keuntungan lain adalah adanya peluang bagi keturunannya untuk lolos dari enkapsulasi inang, karena enkapsulasi telur pertama yang diletakkan telah menghabiskan haemocyt inang. Enkapsulasi oleh inang terhadap benda lain yang masuk ke larva seperti telur parasitoid yaitu dengan menggunakan sel darah atau haemocytnya. Dari telur pertama diletakkan oleh parasitoid akan langsung dienkapsulasi, sehingga telur yang diletakkan berikutnya terbebas dari enkapsulasi (Blumberg, 1997)

Eriborus argenteopilosus Cameron termasuk famili Ichneumonidae ordo Hymenoptera adalah parasitoid beberapa jenis hama dari ordo Lepidoptera seperti hama tanaman kubis, Crocidolomia pavonana Fab. (Lepidoptera: Pyralidae), Spodoptera litura (Lepidoptera: Noctuidae) dan Heliothis armigera (Lepidoptera: Noctuidae) (Kalshoven, 1981). Eriborus termasuk parasitoid koinobiont yang bersifat soliter, hidup dalam tubuh inang dimana inang tetap berkembang dan hanya satu turunan parasitoid yang muncul dari satu inang. Akan tetapi dalam kehidupannya parasitoid ini juga melakukan superparasitisme, hal ini diduga untuk melawan pertahanan oleh inang yaitu berupa enkapsulasi (Sahari 1999). Enkapsulasi juga terjadi terhadap telur dan larva $E$. argenteopilosus oleh inangnya $C$. pavonana (Nelly et al., 2005).

Kerapatan inang dan suhu lingkungan diduga ikut mempengaruhi terjadinya parasitisme dan superparasitisme (Nelly et al., 2005). Sehubungan dengan pemanfaatan parasitoid ini untuk pengendalian hayati, maka perlu diketahui seberapa jauh kerapatan inang dan suhu mempengaruhi terjadinya superparasitime pada E. argenteopilosus. Untuk itu telah dilakukan penelitian dengan tujuan mempelajari pengaruh suhu dan kerapatan inang terhadap kejadian superparasitisme oleh parasitoid E. argenteopilosus.

\section{METODE PENELITIAN}

Tempat dan Waktu. Penelitian dilaksanakan di Laboratorium Bioekologi Parasitoid dan Predator Departemen Proteksi Tanaman, Institut Pertanian Bogor. Waktu pelaksanaan dari bulan Februari sampai April.

Perbanyakan Serangga Inang $C$. pavonana. Larva inang $C$. pavonana dikumpulkan dari pertanaman kubis di daerah Cibodas, Jawa Barat. Larva tersebut dibiakkan di laboratorium dalam kotak plastik pemeliharaan berukuran $35 \times 27 \times 7 \mathrm{~cm}$. Pada dasar kotak diberi alas kertas stensil dan diberi daun kubis sebagai pakan larva. Ketika larva sudah instar empat, diberi serbuk gergaji untuk tempat berpupa. Semua imago jantan dan betina yang muncul dari pupa dipelihara dalam kurungan kain kasa berbingkai kayu berukuran 50 x 50 x $50 \mathrm{~cm}$. Imago tersebut diberi pakan larutan madu 10\% (madu:air $=1: 9$ v/v) yang diserapkan pada segumpal kapas dan digantung dalam kurungan. Untuk tempat peletakan telur bagi imago dimasukkan daun kubis ke dalam kurungan tersebut. Telur dipanen setiap hari dan disimpan dalam cawan petri sampai menetas. Larva instar dua siap dijadikan inang untuk percobaan.

\section{Persiapan Koloni E. Argenteopilosus.} E. argenteopilosus dikoleksi dari tempat yang sama dengan asal inangnya. Imago parasitoid di lapangan ditangkap dengan menggunakan jaring serangga, dan dipelihara di laboratorium dalam kurungan plastik berbentuk tabung (tinggi $23 \mathrm{~cm}$, diameter $12 \mathrm{~cm}$ ). Pakan diberikan adalah larutan madu $10 \%$. Untuk perbanyakan parasitoid, larva inang dipaparkan pada parasitoid selama 24 jam. Inang itu dipelihara dalam wadah plastik (diameter $10 \mathrm{~cm}$ dan tinggi $12 \mathrm{~cm}$ ) sampai pupa 
parasitoid terbentuk. Pupa parasitoid tersebut kemudian dikumpulkan dalam kurungan plastik (tinggi $27 \mathrm{~cm}$, diameter12 cm) sampai imago muncul. Imago betina yang muncul digunakan untuk percobaan atau untuk perbanyakan berikutnya. Pupa parasitoid juga dikoleksi langsung dari larva $C$. pavonana yang dikumpulkan dari lapangan dan dipelihara dilaboratorium. Imago yang muncul dari pupa tersebut juga digunakan langsung untuk percobaan.

\section{Pengaruh Suhu dan Kerapatan Inang terhadap}

Superparasitisme. Penelitian ini menggunakan rancangan acak lengkap faktorial dengan dua faktor perlakuan yaitu: (1) kerapatan inang dan (2) suhu, dengan 10 kali ulangan. Lima kerapatan inang yaitu : 15, 30, 60, 90, dan 120 larva C. pavonana dan suhu 20, 25 , dan $30{ }^{\circ} \mathrm{C}$. Larva inang $C$. pavonana dipaparkan pada sehelai daun brokoli untuk satu parasitoid betina. Daun brokoli ditancapkan pada tabung film yang diberi air untuk menjaga kesegaran daun, dan diletakkan dalam kurungan plastik (tinggi $27 \mathrm{~cm}$, diameter $12 \mathrm{~cm}$ ). Kedalam kurungan dimasukkan satu betina $E$. argenteopilosus (berumur 4-6 hari), selama 3 jam. Untuk pakan parasitoid diberi madu $10 \%$, yang diletakkan pada kapas diatas kurungan. Kurungan diletakkan dalam inkubator (tipe MRL 250) dengan suhu sesuai perlakuan, dan kelembaban nisbih $\pm 70 \%$. Untuk melihat jumlah telur yang diletakkan oleh parasitoid maka setelah larva inang dipaparkan dibedah dan dan diamati di bawah mikroskop binokuler. Superparasitisme diamati berdasarkan peletakan telur yang berjumlah 2 telur atau lebih pada 1 ekor larva inang. Pengamatan dan penghitungan jumlah telur parasitoid yang diletakkan dalam tubuh inang dilakukan pada saat pembedahan.
Analisis Data. Semua data dianalisis menggunakan sidik ragam dengan faktor kejadian superparasit sebagai respons parasitoid akibat perbedaan kerapatan inang dan suhu. Selanjutnya data dianalisis regresi menggunakan Statistix 8.0 dan uji lanjut dengan uji Tukey pada taraf nyata 0,05 . (Analitycal software for windows 2003)

Untuk melihat pengaruh suhu dan kerapatan terhadap superparasitisme dilakukan analisis regresi berganda (PROC REG) dan uji lanjut dengan perkiraan distribusi Poisson pada larva yang berisi 0, 1, 2, 3 dan $>3$ telur parasitoid. Uji $\mathrm{X}^{2}$ dilakukan untuk melihat perbedaan frekuensi superparasitisasi parasitoid, kemudian dibandingkan dengan distribusi perkiraan Poisson (PROC FREQ) (Jones et al., 2003).

\section{HASIL DAN PEMBAHASAN}

Hasil pengamatan menunjukkan bahwa jumlah telur yang diletakan $E$. argenteopilosus pada setiap larva inang dipengaruhi oleh suhu dan kerapatan inang $(\mathrm{df}=2$, $\left.\mathrm{r}^{2}=0,099, \mathrm{P}=0,001 \mathrm{~F}=5,25\right)$. Persentase larva yang mempunyai lebih dari satu telur parasitoid (superparasitisme) tertinggi tejadi pada suhu $20^{\circ} \mathrm{C}(10,00$ $12,67 \%$ ) dan kerapatan inang 15 dan 30 larva. Jumlah telur parasitoid maksimal dalam larva inang ditemukan pada kerapatan 15 larva dan suhu $25^{\circ} \mathrm{C}$ yaitu 9 butir (Tabel 1).

Tidak ada peningkatan superparasitisasi yang nyata dengan meningkatnya kerapatan inang atau sebaliknya $(\mathrm{P}=0,325)$, akan tetapi berdasarkan distribusi Poisson frekuensi superparasitisme berbeda nyata pada semua suhu $(\mathrm{P}=0,001)$. Hal ini menggambarkan bahwa kejadian superparasitisasi terjadi secara acak pada suhu yang berbeda (Tabel 2). Persentase superparasitisme

Tabel 1. Superparasitisme dan telur maksimal yang diletakkan E. argenteopilosus per larva inang pada kerapatan inang dan suhu berbeda

\begin{tabular}{ccccccc}
\hline \multirow{2}{*}{$\begin{array}{c}\text { Kerapat an } \\
\text { inang }\end{array}$} & \multicolumn{2}{c}{20} & \multicolumn{2}{c}{ Persentase superparasitisme pada suhu $\left({ }^{\circ} \mathrm{C}\right)$} \\
\cline { 2 - 6 } & $\begin{array}{c}\text { Rerata }(\%) \\
\pm \mathrm{se}\end{array}$ & $\begin{array}{c}\text { telur } \\
\text { maksimal }\end{array}$ & $\begin{array}{c}\text { Rerata }(\%) \\
\pm \mathrm{se}\end{array}$ & $\begin{array}{c}\text { Telur } \\
\text { maksimal }\end{array}$ & $\begin{array}{c}\text { Rerata }(\%) \\
\pm \mathrm{se}\end{array}$ & $\begin{array}{c}\text { telur } \\
\text { maksimal }\end{array}$ \\
\cline { 2 - 7 } & $10,00 \pm 1,18 \mathrm{a}$ & 3 & $2,00 \pm 1,18 \mathrm{ab}$ & 9 & $5,33 \pm 1,18 \mathrm{a}$ & 2 \\
15 & 3 & $1,85 \pm 1,24 \mathrm{ab}$ & 3 & $5,67 \pm 1,18 \mathrm{a}$ & 2 \\
60 & $6,97 \pm 1,18 \mathrm{bc}$ & 2 & $1,83 \pm 1,18 \mathrm{ab}$ & 2 & $1,67 \pm 1,18 \mathrm{ab}$ & 2 \\
90 & $4,89 \pm 1,18 \mathrm{bcd}$ & 2 & $1,33 \pm 1,18 \mathrm{a}$ & 2 & $1,89 \pm 1,18 \mathrm{ab}$ & 2 \\
120 & $2,33 \pm 1,18 \mathrm{~cd}$ & 3 & $0,25 \pm 1,18 \mathrm{a}$ & 2 & $0,92 \pm 1,18 \mathrm{~b}$ & 2 \\
\hline
\end{tabular}

Angka yang diikuti oleh huruf yang sama menunjukkan tidak berbeda nyata akibat interaksi perlakuan kerapatan inang dan suhu yang berbeda berdasarkan uji Tukey taraf $5 \%$. 
lebih tinggi pada suhu $20^{\circ} \mathrm{C}$, walaupun pada suhu $30^{\circ} \mathrm{C}$ dengan kerapatan inang yang rendah (15 dan 30 larva inang) tidak berbeda nyata dengan suhu $20^{\circ} \mathrm{C}$. Parasitoid lebih mudah menemukan dan memarasitnya berulangulang inang yang tidak begitu aktif, hal ini biasanya terjadi pada suhu rendah $\left(20{ }^{\circ} \mathrm{C}\right)$. Sebaran jumlah telur parasitoid dalam larva inang pada suhu 20, 25 dan 30
${ }^{\circ} \mathrm{C}$. Jika diamati kemampuan memarasit $E$. argenteopilosus pada setiap perlakuan dengan kerapatan inang yang berbeda, pada masing masing suhu yang berbeda terlihat tingkat superparasitisasi lebih kecil dibandingkan dengan yang terparasit dan tidak terparasit. Pada suhu yang $25{ }^{\circ} \mathrm{C}$ lebih banyak jumlah yang terparasit dibandingkan yang tidak, terutama pada

Tabel 2. Persentase parasitasi parasitoid E. argenteopilosus dengan jumlah telur yang diletakan $(1,2$ dan $\geq 3$ telur/larva) pada suhu dan kerapatan inang berbeda (10 ulangan)

\begin{tabular}{ccccc}
\hline \multirow{2}{*}{ Suhu ${ }^{\circ} \mathrm{C}$} & Kerapatan inang & \multicolumn{3}{c}{ \% parasitisasi dengan jumlah telur/larva } \\
\cline { 2 - 5 } & 15 & 93,33 & 2 & $>3$ \\
\hline 20 & 30 & 94,92 & 5,67 & 0,00 \\
& 60 & 95,65 & 2,62 & 0,00 \\
& 90 & 89,09 & 10,91 & 1,73 \\
& 120 & 95,96 & 4,04 & 0,00 \\
& 15 & 94,74 & 5,26 & 0,00 \\
\hline 30 & 30 & 93,33 & 5,56 & 0,00 \\
& 60 & 88,55 & 8,94 & 2,11 \\
& 90 & 96,32 & 3,68 & 0,00 \\
& 120 & 99,50 & 0,50 & 0,00 \\
\hline 30 & 15 & 93,98 & 6,02 & 0,00 \\
& 30 & 95,00 & 4,23 & 0,77 \\
& 60 & 97,91 & 2,09 & 0,00 \\
& 90 & 96,15 & 3,85 & 0,00 \\
& 120 & 98,95 & 1,05 & 0,00 \\
\hline
\end{tabular}

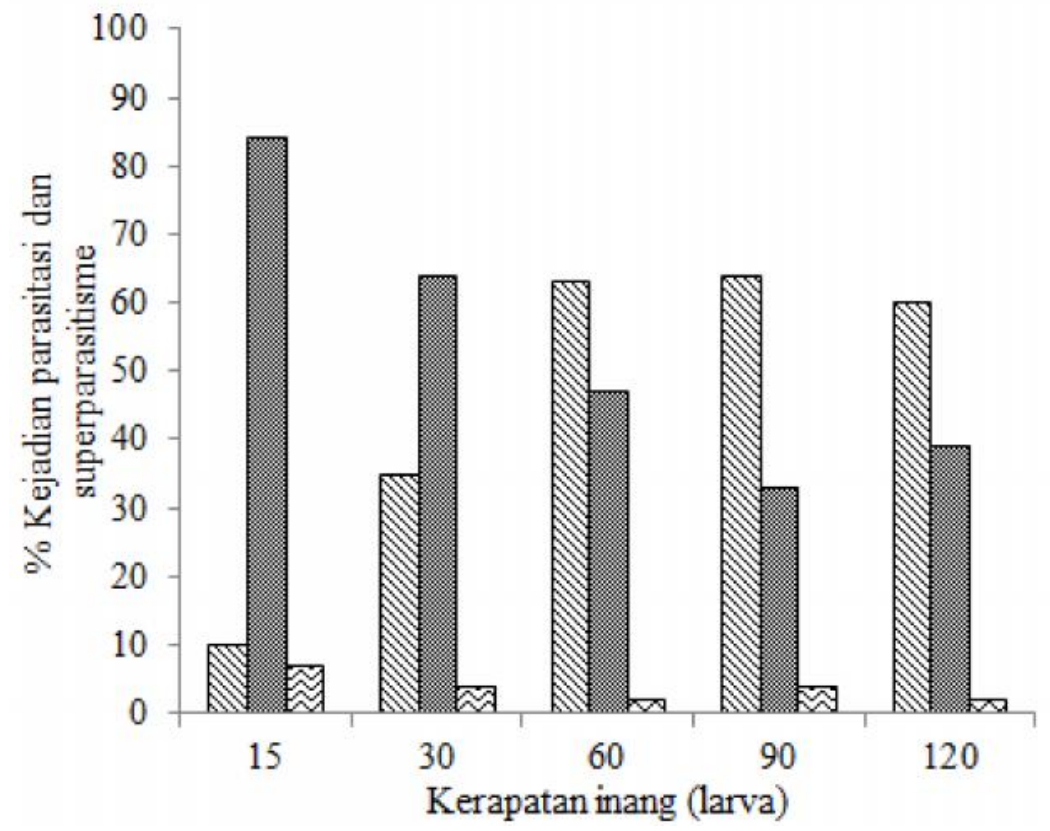

\$tidak terparasit

Interparasit

Vsuperparasitisme

Gambar 1. Pengaruh kerapatan inang terhadap kejadian parasitisasi dan superparasitisasi (pada suhu $20{ }^{\circ} \mathrm{C}$ ) 


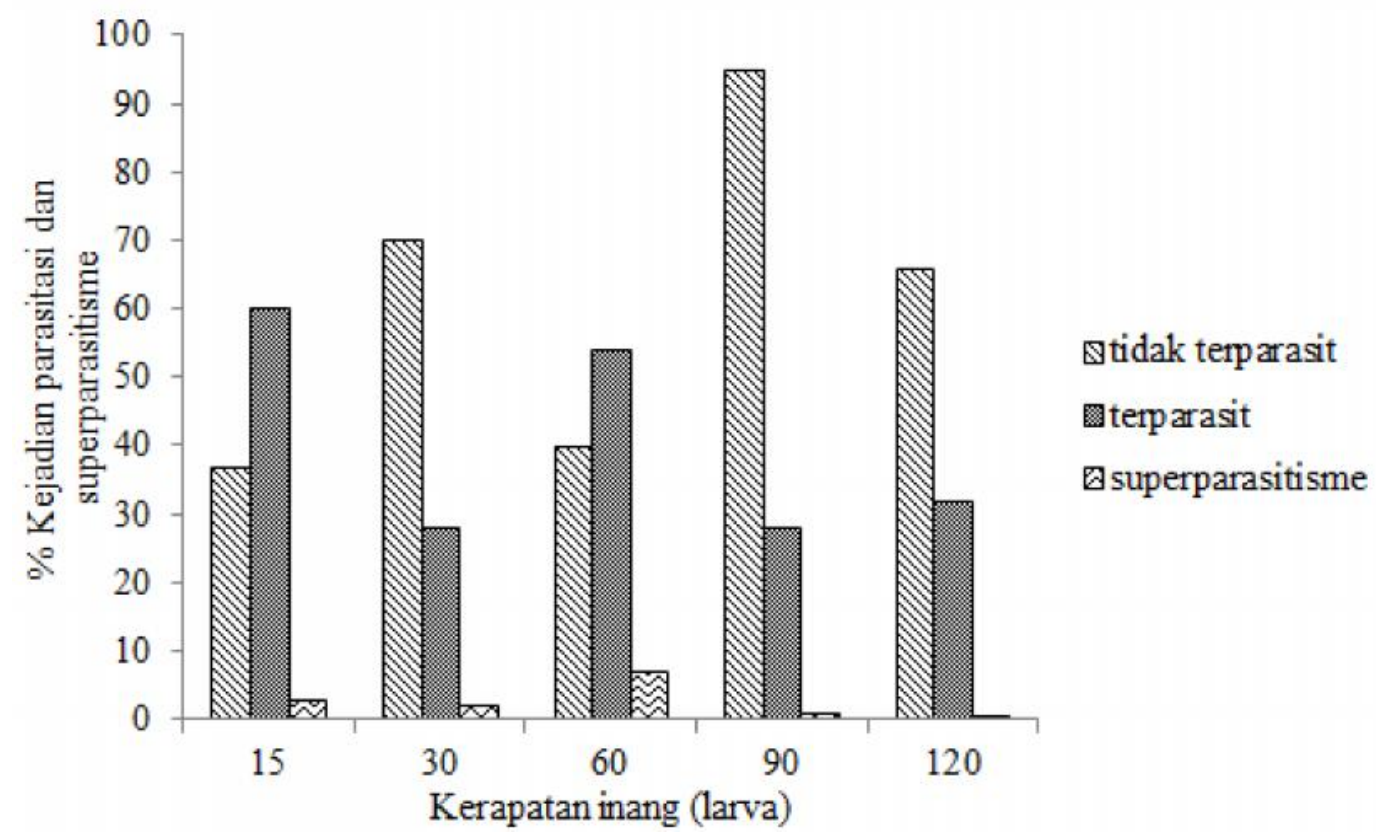

Gambar 2. Pengaruh kerapatan inang terhadap kejadian parasitisasi dan superparasitisasi (pada suhu $25^{\circ} \mathrm{C}$ )

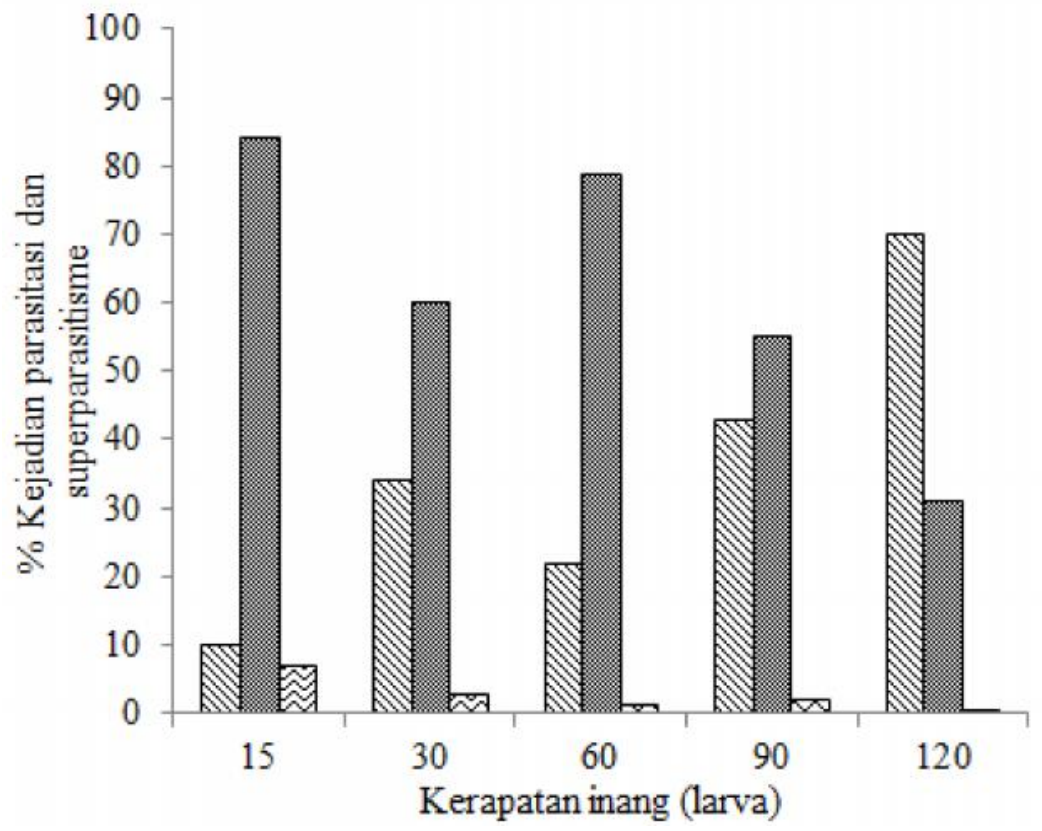

\&tidak terparasit

Iterparasit

Vsuperparasitisme

Gambar 3. Pengaruh kerapatan inang terhadap kejadian parasitisasi dan superparasitisasi (pada suhu $30{ }^{\circ} \mathrm{C}$ )

Tabel 3. Korelasi antara jumlah telur yang diletakkan dan larva inang terparasit oleh E. argenteopilosu pada suhu dan kerapatan inang yang berbeda

\begin{tabular}{lccl}
\hline Faktor & Nilai koefisien korelasi & $\mathrm{N}$ & $\mathrm{P}$ value \\
\hline Suhu dengan jumlah telur & 0,154 & 150 & 0,006 \\
Kerapatan inang dengan jumlah telur & $0,775^{* *}$ & 150 & $0,000^{* *}$ \\
Suhu dengan larva inang terparasit & $0,198^{* *}$ & 150 & $0,000^{* *}$ \\
Kerapatan dengan inang terparasit & $0,800^{* *}$ & 150 & $0,000^{* *}$ \\
\hline
\end{tabular}

${ }^{* *}$ Korelasi signifikan pada taraf $1 \%$. 
kerapatan inang yang rendah. Sedangkan superparasitisasi selalu ada pada kerapatan inang yang berbeda walaupun dengan jumlah yang rendah (Gambar 1, 2, dan 3).

Secara keseluruhan jika dilihat interaksi inangparasitoid, terlihat ada korelasi antara: suhu, kerapatan inang, dengan jumlah larva terparasit $(\mathrm{P}=0,000)$. Jumlah larva inang terparasit berkorelasi dengan suhu. Demikian juga larva inang terparasit berkorelasi dengan kerapatan inang. Jika dilihat dari satu faktor suhu saja, maka tidak ada korelasi dengan jumlah telur yang diletakkan $(\mathrm{P}=$ 0,006) (Tabel 3).

Dari hasil pengamatan kejadian superparasitisasi pada E. argenteopilosus terlihat suhu dan kerapatan inang berpengaruh untuk terjadinya superparasitisasi. Namun, distribusi superparasitisasi pada kerapatan berbeda terjadi secara acak, hal ini terjadi karena parasitoid ini selalu aktif untuk mencari inang. $E$. argenteopilosus dalam pencarianinangnya selalu menggerakkan antena atau melakukan drumming. Bila bertemu dengan inang ovipositornya langsung ditusuk ke larva inang yang ditemuinya untuk peletakkan telur. E. argenteopilosus sepertinya tidak bisa mengenali inang yang sudah atau belum terparasit (hostdiscrimination), hal ini dilihat bahwa superparasitisasi selalu terjadi pada setiap suhu dan kerapatan berbeda. Walaupun secara keseluruhan persentase superparasitisme dari semua ulangan rendah sekali dibandingkan dengan yang larva dengan 1 telur, hanya berkisar 0,1 sampai $6,8 \%$.

Hasil analisis distribusi Poisson menunjukkan bahwa superparasitisme terjadi secara acak pada semua kerapatan. Jika hanya diamati pengaruh suhu atau kerapatan saja, tidak memperlihatkan pengaruh untuk terjadi superparasitisasi. Namun, secara bersama suhu dan kerapatan inang berpengaruh untuk terjadi superparasitisasi. Dalam hal ini aktivitas inang dan parasitoidnya dipengaruh lingkungan secara bersamasama. Pada kerapatan inang dan suhu tertentu laju pencarian oleh $E$. argenteopilosus menjadi lebih rendah, karena inang lebih mudah ditemukan.

Pada penelitian ini jumlah inang yang ditemukan sangat mempengaruhi kejadian superparasitisme. Semakin sedikit atau kerapatan inang yang rendah akan semakin tinggi kemungkinan terjadinya superparasitisme. Demikian juga dengan kondisi parasitoid itu sendiri, peluang untuk terjadi superparasitisasi akan meningkat dengan semakin banyaknya jumlah parasitoid pada patch yang sama dan masih banyaknya telur yang terdapat dalam ovari yang belum diletakkan. Faktor yang menyebabkan terjadinya superparasitisme yaitu: bila inang yang belum terparasit jarang atau tidak ada ditemui, laju penemuan inang yang rendah, pengaruh adanya betina lain yang juga mencari inang pada tempat yang sama (Godfray, 1994).

Pada saat kerapatan 60 dan 90 larva inang di bawah suhu 20 dan $25^{\circ} \mathrm{C}$ laju penerimaan inang lebih kecil. Hal ini terjadi karena pada saat itu aktifitas inang tidak terlalu banyak, sehingga mudah ditemukan oleh parasitoid. Ketika parasitoid menemukan inang yang sama, ovipositornya tetap ditusukkan ke larva inang tersebut sehingga akan terjadi beberapa kali peletakan telur, hal ini menyebabkan terjadinya superparsitisasi.

Kejadian superparasitisme atau peletakkan telur oleh parasitoid pada inang yang sama sebenarnya merupakan suatu kerugian bagi parasitoid tersebut. Pada kebanyakan parasitoid dapat mendeteksi keberadaan parasitoid lain atau telur yang sudah diletakkan pada inang. Hal ini ini juga akan mempengaruhi kebugaran parasitoid. Hasil penelitian pada Pimpla niponica (Hymenoptera: Ichneumonidae) yaitu parasitoid soliter pada berbagai pupa Lepidoptera. Jika terjadi superparasitisme dapat menyebabkan menurunnya persentase kemunculan dewasa parasitoid dan meningkatkan kematian pradewasa baik pada stadia telur maupun instar awal (Ueno, 1997).

Selanjutnya jika parasitisasi terjadi pada $E$. argenteopilosus, inang tetap berkembangwalaupun perkembangannya lebih lambat dibanding inang sehat. E. argenteopilosus yang merupakan parasitoid soliter dalam kehidupannya melakukan self superparasitisasi yaitu memarasit larva inang yang sudah diparasiti sebelumnya. Sehingga sering kali menyebabkan terjadinya superparasitisme. Sebenarnya kejadian superparasitisme oleh parasitoid dapat menguntungkan karena memberi peluang bagi keturunannya untuk lolos dari enkapsulasi akibat pertahanan inang. Akibat enkapsulasi pada telur pertama yang diletakkan mungkin telah menghabiskan cadangan haemocyt inang sehingga telur yang diletakkan berikutnya terbebas dari enkapsulasi. Apabila telur diletakkan secara tunggal pada inang maka semua telur akan terenkapsulasi. Hal ini dapat dilihat sewaktu pegamatan pembedahan dan penghitungan jumlah telur parasitoid pada larva inang.Jika telur yang diletakkan oleh parasitoid dalam inang lebih banyak, maka parasitoid tersebut akan lolos dari kematian.

Jadi kejadian superparasitisme tersebut sepertinya sengaja dilakukan oleh parasitoid, walaupun jumlah inang yang tersedia banyak. Artinya pada kerapatan inang yang tinggi kejadian superperasitisme tetap terjadi, apalagi jika pada suhu yang optimal (Tabel 4). 
Tabel 4. Jumlah total larva inang dengan sebaran telur yang diletakkan parasitoid E. argetenteopilosus pada suhu dan kerapatan inang berbeda (10 ulangan)

\begin{tabular}{|c|c|c|c|c|c|c|c|c|c|c|c|c|c|c|c|}
\hline \multirow{4}{*}{$\begin{array}{l}\text { Jumlah } \\
\text { telur } \\
\text { per larva }\end{array}$} & \multicolumn{15}{|c|}{ Suhu $\left({ }^{\circ} \mathrm{C}\right)$} \\
\hline & \multicolumn{5}{|c|}{$20^{\circ} \mathrm{C}$} & \multicolumn{5}{|c|}{$25^{\circ} \mathrm{C}$} & \multicolumn{5}{|c|}{$30^{\circ} \mathrm{C}$} \\
\hline & \multicolumn{15}{|c|}{ kerapatan inang (larva) } \\
\hline & 15 & 30 & 60 & 90 & 120 & 15 & 30 & 60 & 90 & 120 & 15 & 30 & 60 & 90 & 120 \\
\hline 0 & 15 & 103 & 370 & 561 & 705 & 55 & 210 & 242 & 628 & 799 & 17 & 40 & 122 & 380 & 818 \\
\hline 1 & 126 & 187 & 220 & 302 & 475 & 90 & 84 & 317 & 262 & 399 & 125 & 247 & 468 & 500 & 378 \\
\hline 2 & 9 & 10 & 6 & 37 & 20 & 5 & 5 & 32 & 10 & 2 & 8 & 11 & 10 & 20 & 4 \\
\hline$>3$ & 0 & 0 & 4 & 0 & 0 & 0 & 1 & 9 & 0 & 0 & 0 & 2 & 0 & 0 & 0 \\
\hline Total & 150 & 300 & 600 & 900 & 1200 & 150 & 300 & 600 & 900 & 1200 & 150 & 300 & 600 & 900 & 1200 \\
\hline
\end{tabular}

Adaptasi oleh parasitoid terhadap inang juga sangat menentukan kejadian superparasitisme, laporan Blumberg et al. (1990) yang menyatakan Comperiella bifasciata strain California kurang beradaptasi dengan California red scale dibandingkan strain Israel, ternyata strain California tersebut meletakkan telurnya secara tunggal dan kebanyakan di enkapsulasi oleh California red scale dibandingkan strain Israel.

Jumlah telur yang diletakkan parasitoid sangat menentukan kelangsungan hidupnya. Hasil pengamatan Van Alphen \& Visser (1990), bila telur Asobara tabida yaitu parasitoid larva Drosophila melanogaster diletakkan secara tunggal maka survivalnya hanya $1 \%$, sedangkan jika diletakkan lebih dari 1 telur atau bersifat superparasitisme maka survivalnya adalah $7 \%$.

Pada suhu yang optimal $\left(20^{\circ} \mathrm{C}\right)$ dan kerapatan inang tertentu menyebabkan kejadian superparasitisasi. Montoya et al. (2012) juga menyatakan bahwa superparasitisme akan mempengaruhi sex ratio parasitoid. Van Alphen \& Visser (1990), memperlihatkan bahwa superparasitisme adalah faktor penting yang mengatur stabilitas interaksi inang-parasitoid. Dalam konteks ini, parasitoid E. argenteopilosus melakukan superparasitisasi pada inang $C$. pavonana diduga adalah salah satu strategi untuk mengatasi pertahanan inang. Semakin sedikit jumlah inang yang ditemukan, maka sering inang yang sama akan diparasitisasi oleh parasitoid tersebut.

\section{SIMPULAN}

Suhu dan kerapatan inang bersama-sama mempengaruhi $E$. argenteopilosus untuk melakukan superparasitisasi. Superparasitisasi terjadi secara acak pada kerapatan inang yang berbeda. Superparasitisasi paling tinggi terjadi pada suhu $20^{\circ} \mathrm{C}$ dan $25^{\circ} \mathrm{C}$ dengan kerapatan inang 60 dan 90 ekor larva, dengan rata rata 4,4 dan 4,6 larva per 3 jam. Persentase superparasitisme oleh parasitoid ini berkisar antara $0,1-6,8 \%$ dari inang yang dipaparkan.

\section{SANWACANA}

Terima kasih yang sebesar besarnya kepada Kepala Laboratorium Bioekologi Parasitoid dan Predator Departemen Proteksi Tanaman Faperta IPB, dan Direktur Yayasan PEKA Indonesia, atas semua fasilitas yang diberikan untuk pelaksanaan penelitian ini.

\section{DAFTAR PUSTAKA}

Blumberg D. 1997. Encapsulation of parasitoids. In: Ben-Dov Y \& Hodgson CJ (Eds.). World Crop Pest: Soft Scale Insects their Biology, Natural Enemies and Control. Volume 7, Part A. pp. 375-387.

Blumberg D, Luck RF, Flanders SE, Teran AL, \& DeBach P. 1990. Differences in the rates of superparasitism between two strains of Comperiella bifasciata (Howard) parasitizing California red scale (Homoptera: Diaspididae): An adaptation to circumvent encapsulation. Ann. Entomol. Soc. Am. 83: 591-597.

Godfray HCJ. 1994. Parasitoids, Behavioral and Evolutinary Ecology. Princeton University Press. Princeton. New Jersey.

Hamelin F, Bernhard P, \& Wajnberg E. 2007. Superparasitism as a differential game. Theori Popul. Biol. 72(3): 366-378. 
Harvey JA, Poelman EH, \& Tanaka T. 2013. Intrinsic inter- and intraspecific competition in parasitoid wasps. Annu. Rev. Entomol. 58: 333-351.

Husni, Jauharlina, \& Haraqal AA. 2011. Pengaruh superparasitisme terhadap perkembangan progenin parasitoid Tetraticuhus brontispae F. J. Floratek. 6: 28-36.

Jones DB, Giles KL, Berbearet RC, Royer TA, Elliott NC, \& Rayton ME. 2003. Fuctional respon of an introduction parasitoid and indigenous parasitoid on greenbug at four temperature. Environ. Entomol. 32(3): 425-432.

Kalshoven LGE. 1981. The Pests of Crops in Indonesia. (Revised and translated: P.A. van Der Laan). P.T. Ichtiar BaroeVan Hoeve. Jakarta.

Montoya P, Lachaud GP, \& Liedo P. 2012. Superparasitism in the fruit fly parasitoid Diachasmimorpha longicaudata (Hymenoptera: Braconidae) and the implicationsfor mass rearing and augmentative release. Insects 3(4): 900-911.

Nelly N, Buchori D, Habazar T, Syahni R \& Sahari B. 2005. Tanggap fungsional parasitoid Eriborus argenteopilosus (Cameron) terhadap Crocidolomia pavonana (Fabricius) pada suhu yang berbeda. Hayati J. Biossciences 12(1): 17 22.
Quicke DLJ. 1997. Parasitic Wasp. Chapman and Hall. London.

Sahari B. 1999. Studi enkapsulasi parasitoid Eriborus argenteopilosus Cameron (Hymenoptera; Ichneumonidae) dan Implikasinya pada inang Crocidolomia binotalis Zeller (Lepidoptera; Pyralidae) dan Spodoptera litura Fabricius (Lepidoptera: Noctuidae). Skripsi. Institut Pertanian Bogor.

Ueno T. 1997. Effect of superparasitism, larval competition, and host feeding on offspring fittness in the parasitoid Pimpla nipponica (Hymenoptera: Ichneumonidae). Ann. Entomol. Soc. Am. 95(5): 682-688.

VanAlphen JM \& Visser ME. 1990. Superparasitsm as an adaptive strategy for insect parasitoids. Annu. Rev. Entomol. 35: 59-79.

Visser ME, Luyckx B, Nell HW, \& Boskamp GJF. 1992. Adaptive superparasitism in solitary parasitoids: marking of parasitized host in relation to the pay off from superparasitism. Ecol. Entomol. 17: 7682.

Waage JK. 1986. Family planning in parasitoid: adaptive patterns of progeny and sex allocation. In: Waage J \& Greathhead D (Eds.). Insect Parasitoids. pp. 63-95. Academic Press London. 